Article

\title{
Improved Detectivity for Detecting Gas Hydrates Using the Weighted Differential Fields of the Marine Controlled-Source Electromagnetic Data
}

\author{
Gang Li ${ }^{1,2} \mathbb{D}$, Fugui Tang ${ }^{1}$, Chaofan $\operatorname{Li}^{1}$, Wen Lei ${ }^{1}$ and Ying Liu ${ }^{3, *(\mathbb{D}}$ \\ 1 Department of Marine Sciences, Zhejiang University, Zhoushan 316021, China; gangli@zju.edu.cn (G.L.); \\ 21934060@zju.edu.cn (F.T.); 22134113@zju.edu.cn (C.L.); 22034104@zju.edu.cn (W.L.) \\ 2 Hainan Institute, Zhejiang University, Sanya 572025, China \\ 3 Key Lab of Submarine Geosciences and Prospecting Techniques, MOE and College of Marine Geosciences, \\ Ocean University of China, Qingdao 266100, China \\ * Correspondence: liouying@ouc.edu.cn
}

check for

updates

Citation: Li, G.; Tang, F.; Li, C.; Lei, W.; Liu, Y. Improved Detectivity for Detecting Gas Hydrates Using the Weighted Differential Fields of the Marine Controlled-Source

Electromagnetic Data. J. Mar. Sci.

Eng. 2022, 10, 161. https://doi.org/ 10.3390/jmse10020161

Academic Editors: José A.F.O.

Correia and Dejan Brkić

Received: 12 December 2021

Accepted: 25 January 2022

Published: 26 January 2022

Publisher's Note: MDPI stays neutral with regard to jurisdictional claims in published maps and institutional affiliations.

Copyright: (C) 2022 by the authors. Licensee MDPI, Basel, Switzerland. This article is an open access article distributed under the terms and conditions of the Creative Commons Attribution (CC BY) license (https:// creativecommons.org/licenses/by/ $4.0 /)$.

\begin{abstract}
Gas hydrate is seen as a kind of new energy resources, yet it may also be one of the main greenhouse gases as its dissociation may release methane into the atmosphere. Furthermore, a severe hazard to offshore infrastructures may also be introduced by extensive gas hydrate dissociation associated with the stability of the geological structures after gas production. Therefore, it is essential to investigate the gas hydrate as well as its environmental impacts before drilling and extracting it. The geophysical seismic reflection data is usually used for exploring the gas hydrate. The gas hydrate can be effectively identified by the bottom simulating reflectors (BSRs) on seismic reflection data. However, the BSR is only for identifying the bottom boundary and it is difficult to estimate its space distribution and saturation within the hydrate stability zone. The marine controlled-source electromagnetic (CSEM) data is suitable for detecting the gas hydrate as the resistivity of the seafloor increases significantly in the presence of gas hydrate or free gas. In this study, a weighted differentialfield method is applied to improve the detectivity for identifying the gas hydrate. Numerical tests show that the difference of the EM fields can effectively suppress the airwaves in shallow waters. Therefore, the detectivity given by the field ratio between the models with and without the gas hydrate target is enhanced.
\end{abstract}

Keywords: gas hydrate; detectivity; marine electromagnetics

\section{Introduction}

Gas hydrate is a kind of ice-like solid substances which is usually distributed under high pressure and low temperature conditions (e.g., [1,2]). Gas hydrate is mainly composed of water and gas and it contains large amounts of methane. It is now seen as a kind of new energy resources [3]. Furthermore, the gas hydrate may also be a kind of greenhouse gases [4]. Although some of it may be trapped under the seafloor and and consumed by some microbes [2], the hydrate could be dissociated with methane released into the atmosphere if the stability of the geological structures were destroyed after gas production. Furthermore, extensive gas hydrate dissociation may also pose a severe hazard to offshore infrastructures [5]. Therefore, it is essential to investigate and quantify the gas hydrate and access its environmental impacts before its production. There are some recently developed techniques for dealing with this issue. For example, Hassanpouryouzband et al. [6] proposed the way for the permanent geological storage of $\mathrm{CO}_{2}$ and related methane in permafrost regions and marine sediments which could greatly reduce the cost of capturing and storing the gas hydrate.

Geophysical methods are widely used for exploring the gas hydrate [3,7-9]. For example, high-resolution acoustic investigations including side-scan sonar imagery and 
shallow subbottom profiling of the seafloor have indicated the presence of pockmarks, acoustic maskings and seeps. Acoustic anomalies associated with the gas seepage are observable within sediments of characteristic features in the seabed [10-12]. The pressure coring and seafloor marine heat flux measurements are also used for its accurate borehole investigations [8]. The high-resolution seismic profiles are usually used for investigating the gas hydrate deposits before drilling [13-18]. The stable gas hydrate zone is usually buried by a layer of free gas which will cause a seismic impedance contrast called the bottom simulating reflection (BSR) (e.g., [19]). Its bottom boundary can be identified from the BSRs qualitatively. However, it is not easy for us to quantify the gas hydrate deposits by the seismic reflection method only.

The marine electromagnetic (EM) method, especially the marine controlled-source EM (CSEM) technique, is widely used for investigating the gas hydrate [20-38]. The presence of methane or free gas increase the resistivity of the gas hydrate zone significantly $[21,39,40]$, thus the EM method is useful for detecting the space distribution of hydrate in natural sediments, estimating its saturation [41-44] and monitoring the formation and dissociation of hydrates with the help of the borehole data [45-48]. Furthermore, the marine CSEM resistivity profiles can be used to indicate the fluid composition and migration pathways beneath the pockmarks [49]. Below the base of gas hydrate stability zone, sediments contain only free gas or water dissolved gas, such as gas seeps, vents or mud volcanoes [50-55]. As mentioned above, the free gas could be distinguished from the sediments while not for the water dissolved gas.

The marine CSEM method usually applies a towed dipole transmitter emitting low frequency EM signals [56-59]. The receivers can be deployed on the seafloor [60] or towed behind the source $[28,61]$. For shallow waters where the gas hydrate is usually buried, the airwave dominates the recorded EM signals and it will mask the useful signals from the seafloor hydrate target [62-66]. The airwave is mainly the signals from the source which propagates upward to the sea surface, travels through the air horizontally and finally goes down into the water column to the receivers [67]. As the air and seawater have an extreme physical contrast, the critical angle for total reflection between air and seawater is almost the incidence angle [68]. The energy of the airwave is strong, especially in shallow waters of depth no more than $300 \mathrm{~m}$. Thus, it is necessary to suppress the airwave before processing and interpreting the marine CSEM field data [69].

The way to suppress the airwave in shallow waters are well investigated in previous studies. For example, Amundsen et al. [67] proposed the decomposition of EM fields to retract and remove the airwave from downgoing components. One can also evaluate the airwave analytically for $1 \mathrm{D}$ conductivity model and then remove it [62,70-72]. The 1D method is usually not suitable for the earth with topography or with complex geological structures. Løseth et al. [63] presented the weighted differences of EM fields to attenuate the airwave. The weighted differential approach is proved to be effective in suppressing the airwave and it can be utilized for dealing with both 1D and multi-dimensional (2D or 3D) data sets.

In this paper, we apply the weighted differential method proposed by Løseth et al. [63] to suppress the airwave of the marine CSEM data for identifying the gas hydrate targets. It is worth mentioning that, in our tests, the resistivity contrast between the hydrates and sediments is not as high as the hydrocarbon examples used by Løseth et al. [63]. This paper is organized as follows. First, we give the theory of computing the weighted differential fields. Then, some numerical tests are presented. Finally, a conclusion is given and future work is discussed. 


\section{Methodology}

In this section, we give the principles of calculating the weighted differential EM fields. Following $\mathrm{Li}$ and $\mathrm{Li}[73,74]$, the electric and magnetic fields due to a dipole source for the layered conductivity medium can be expressed as

$$
\begin{aligned}
& E\left(x_{S}, y_{S}, z_{S}, x, y, z\right)=P\left(x_{S}, y_{S}, x, y\right) \int_{0}^{\infty} \sum_{v=0}^{1} f_{v}^{E}\left(\sigma, z_{S}, z, \lambda\right) J_{v}(\lambda r) d \lambda, \\
& H\left(x_{S}, y_{S}, z_{S}, x, y, z\right)=P\left(x_{S}, y_{S}, x, y\right) \int_{0}^{\infty} \sum_{v=0}^{1} f_{v}^{H}\left(\sigma, z_{S}, z, \lambda\right) J_{v}(\lambda r) d \lambda,
\end{aligned}
$$

in which the parameters used in above Equations (1) and (2) are listed as follows

- $\quad E$ : the electric field;

- $H$ : the magnetic field;

- $\quad\left(x_{S}, y_{S}, z_{S}\right)$ : the position of the dipole source;

- $(x, y, z)$ : the position of the receiver;

- $\quad P\left(x_{S}, y_{S}, x, y\right)$ : the dipole source moment related to the horizontal positions of the dipole source and the receiver;

- $\quad r=\left[\left(x-x_{S}\right)^{2}+\left(y-y_{S}\right)^{2}\right]^{1 / 2}$ : the horizontal distance between the dipole source and the receiver;

- $\quad J_{v}(\lambda r)$ : the Bessel function of the first kind of the order $v$, where $v$ can be 0 or 1 ;

- $f_{v}^{E}\left(\sigma, z_{S}, z, \lambda\right)$ : the corresponding kernel functions for the electric field;

- $f_{v}^{H}\left(\sigma, z_{S}, z, \lambda\right)$ : the corresponding kernel functions for the magnetic field.

Figure 1 shows the main propagation paths of different EM waves induced by a dipole source. As mentioned before, the airwave is part of the propagating EM fields (see Equations (1) and (2)) mainly reflected from the sea surface (red line in Figure 1). The hydrate target related EM signals are the reflection wave and the guided wave, which are indicated by the yellow line and the black line, respectively.

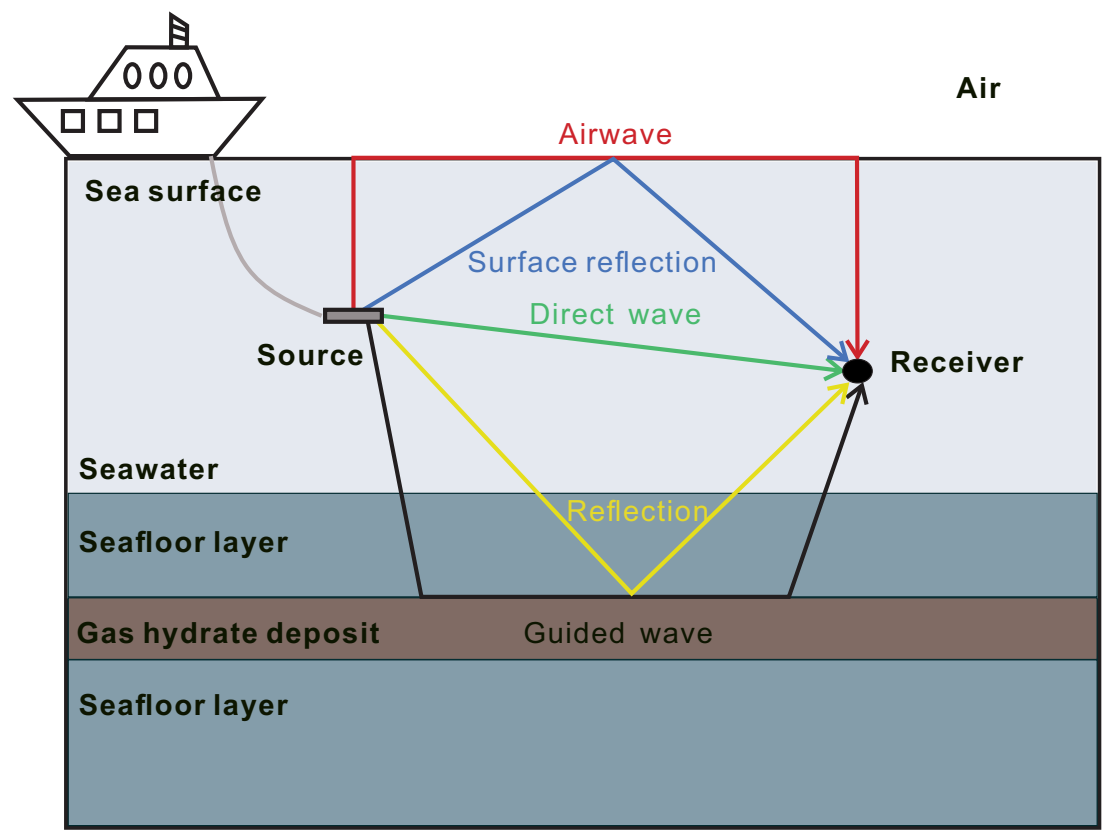

Figure 1. Illustration of the field events due to a dipole source in the marine environment (modified after [67]). For the 1D conductivity earth, the source induced airwave (magenta), the surface reflection wave (blue) and the direct wave (green) are mainly going upward, while the reflection wave (yellow) and the guided wave (black) related to the gas hydrate deposit are going downward. 
Furthermore, in the frequency domain, for a simplified model with dual air-seafloor half-spaces and a finite-thick seawater column as the interlayer, the electric part of the airwave can be expressed as [62]

$$
E_{r}^{a i r}=\frac{P \cos \phi e^{\mathrm{i} k\left(z+z_{S}\right)} e^{\mathrm{i} k_{0} r}}{2 \pi \sigma_{s e a} r^{3}} \frac{1+R e^{2 \mathrm{i} k\left(z_{b}-z_{S}\right)}}{1-R e^{2 \mathrm{i} k z_{b}}} \frac{1+R e^{2 \mathrm{i} k\left(z_{b}-z\right)}}{1-R e^{2 \mathrm{i} k z_{b}}}
$$

where

- $\quad \mathrm{i}=\sqrt{-1}$ : the imaginary unit;

- $\phi$ : the azimuth of the dipole source, and $\phi$ is set to be 0 for a horizontal source along the eastern direction $y$;

- $\omega$ : the angular frequency;

- $\quad \mu_{0}$ : the magnetic permeability in free space;

- $\epsilon_{0}$ : the electric permittivity in free space;

- $\sigma_{\text {sea }}$ : the conductivity of the seawater;

- $\sigma$ : the conductivity of the seabed;

- $k=\sqrt{\mathrm{i} \omega \mu_{0} \sigma_{\text {sea }}}$ : the wavenumber used;

- $k_{0}=\omega \sqrt{\mu_{0} \epsilon_{0}}$ : the wavenumber in free space;

- $z_{b}$ : the seawater depth;

- $R=\left(\sqrt{\sigma_{\text {sea }}}-\sqrt{\sigma}\right) /\left(\left(\sqrt{\sigma_{\text {sea }}}+\sqrt{\sigma}\right)\right)$ : the reflection coefficient of TE mode for the seabed. From Equations (1)-(3) we can see that the horizontal electric field component of the airwave is inverse to the power of three with respect to the source-receiver horizontal offset $r$. We also find that the horizontal magnetic field component is inverse to the power of four with respect to $r$ [63]. By weighting the horizontal electric field with $r^{3}$ and the horizontal magnetic field with $r^{4}$, the airwave may be attenuated in the measured data as the EM field propagation is mainly vertical $[63,75]$. This quantitative relationship can also be applied to the nonuniform conductivity settings under the seafloor. Therefore, the weighted differential electric field can be expressed as [63]

$$
E_{r_{12}}=\frac{\left(r_{2} / r_{12}\right)^{3} E_{r_{2}}-\left(r_{1} / r_{12}\right)^{3} E_{r_{1}}}{y_{r_{2}}-y_{r_{1}}},
$$

where $E_{r_{12}}$ is the weighted differential electric field for two receivers nearby. The receivers are along the $y$-axis. $r_{12}=\left(r_{1}+r_{2}\right) / 2$, where $r_{1}$ and $r_{2}$ are the horizontal distance between the source used and the receivers 1 and 2, respectively. Here the geometric term $r^{3}$ is considered for suppressing the airwave. Equation (4) is an example for computing weighted differences for inline electric fields of two receivers nearby. The weighted differential magnetic fields for both inline and broadside modes can be calculated similarly. We will not repeat it here for clarity.

\section{Numerical Analysis}

In this section, the numerical analysis for gas hydrate deposit models in shallow waters is shown. Our aim is to validate the weighted differential approach in suppressing the airwave for both $1 \mathrm{D}$ and $2 \mathrm{D}$ cases.

\subsection{D Test}

We first test a 1D gas hydrate model modified after Constable and Weiss [76] (Figure 2). The hydrate reservoir model is composed of five layers including the air, the seawater and seafloor sediments and gas hydrate. The setting of the resistivity of the hydrate is following Goswami [4]. The air is a half-space of the resistivity $10^{12} \Omega \mathrm{m}$ (i.e., the conductivity is $10^{-12} \mathrm{~S} / \mathrm{m}$ ). The seawater layer is of thickness $100 \mathrm{~m}$ and its resistivity is $0.3 \Omega \mathrm{m}$. From the depth of $1100 \mathrm{~m}$, there is a gas hydrate layer of thickness $50 \mathrm{~m}$ and its resistivity is $15 \Omega \mathrm{m}$. The background sediments are of the resistivity $1.5 \Omega \mathrm{m}$. An electric dipole source is placed at $\left(x_{s}=0 \mathrm{~m}, y_{s}=0 \mathrm{~m}, z_{s}=850 \mathrm{~m}\right)$. The transmitting frequencies used are 0.5 
and $1.25 \mathrm{~Hz}$ for detecting shallow hydrate targets following Schwalenberg et al. [31]. The seafloor receivers are distributed evenly along the inline direction $y$ from $500 \mathrm{~m}$ to $9500 \mathrm{~m}$. The receiver interval is $100 \mathrm{~m}$. We use the code given by $\mathrm{Li}$ and $\mathrm{Li}$ [73] to compute the frequency-domain 1D marine CSEM fields.

a)

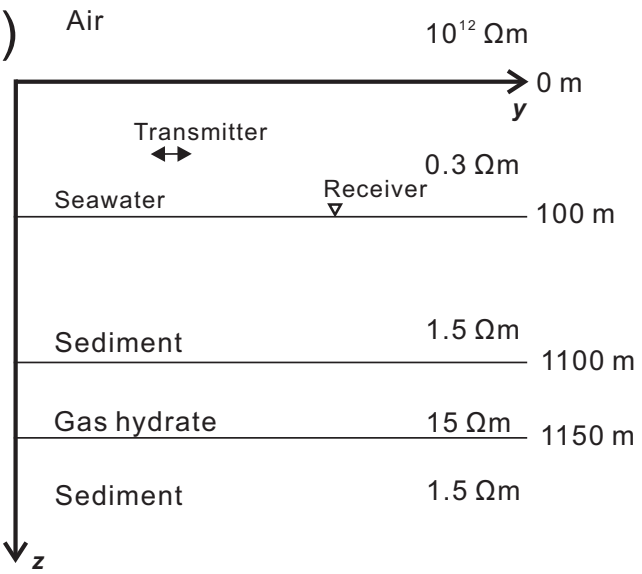

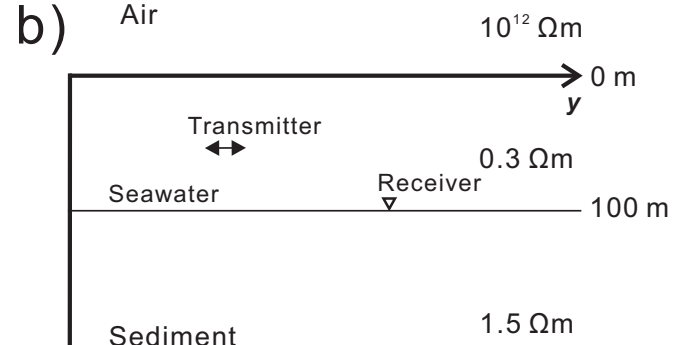

Sediment

Figure 2. The 1D gas hydrate conductivity model (a) and its background model (b) without the hydrate layer.

Figure 3 shows the inline electric field and its weighted differences (see solid and inverse triangles in Figure 3a) and the corresponding detectivity (see the solid line and diamonds in Figure 3b). Note that the amplitude of the inline electric field and its weighted differences for the background model (Figure 2b) is also given for comparison (see dashed line and dots in Figure 3b). The transmitting frequencies 0.5 and $1.25 \mathrm{~Hz}$ are indicated by gray and red, respectively.

From Figure $3 a$ we can see that the amplitude of the weighted differential field is quite smaller than that for the original electric field. The amplitude for the original electric field ranges from $10^{-8}$ to $10^{-12} \mathrm{~V} / \mathrm{Am}^{2}, 1 / \mathrm{m}^{2}$, while it is $10^{-9}$ to $10^{-18} \mathrm{~V} / \mathrm{Am}^{2}, 1 / \mathrm{m}^{2}$ for the weighted differential field. This can explained by the fact that the differential field is weighted by the geometric spreading term and it is decreased remarkably as the transmitter-receiver offset increases. When using the original electric field, the detectivity using the frequencies 0.5 and $1.25 \mathrm{~Hz}$ is almost unity, which indicates that the original electric field is almost of the same as its corresponding background field, i.e., the airwave dominates and it masks the useful signals from the buried hydate target. We can not use the original electric field to detect the hydrate reservoir directly (see solid lines in Figure 3b). However, the detectivity is remarkably improved when using the weighted differential field (see diamonds in Figure 3b). This indicates that by using the weighted differential field, the airwave is suppressed effectively, while the signals for the hydrates are enhanced.

\section{2. $2 D$ Test}

We also test a 2D model to further investigate the weighted differential method. The 2D model (Figure 4) is modified after the 1D case (Figure 2), except that its hydrate deposit is of finite horizontal length of $8000 \mathrm{~m}$. The transmitter-receiver layout is the same as in the $1 \mathrm{D}$ test. The receivers are along the inline direction $y$ from $500 \mathrm{~m}$ to $5500 \mathrm{~m}$ with an even interval $100 \mathrm{~m}$. The code given by Li and Han [30] and Li et al. [37] is used to perform the frequency-domain 2D marine CSEM field simulation. 

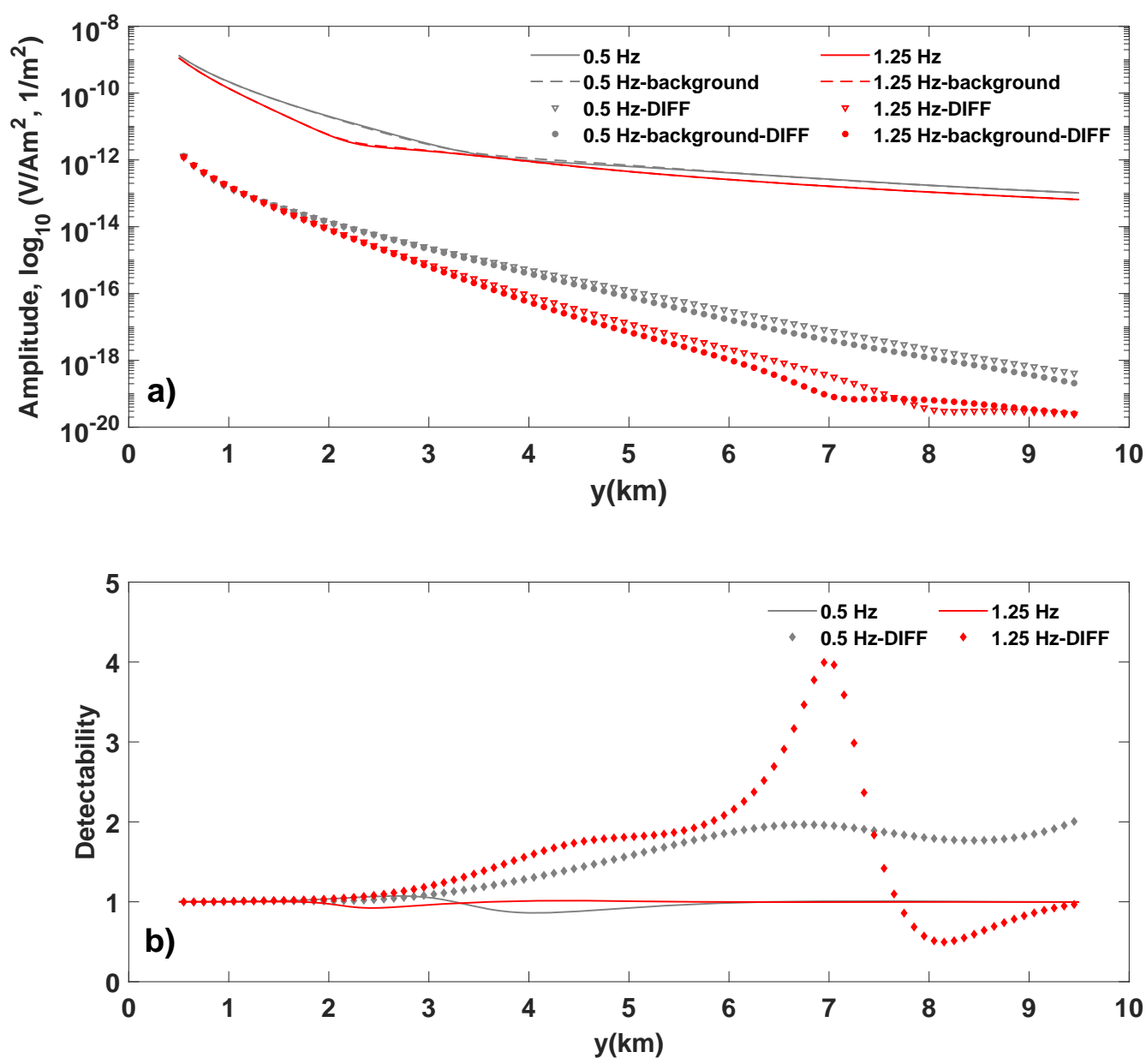

Figure 3. The amplitude of inline electric field and its weighted differences (a), and the corresponding detectivity (b) for the 1D gas hydrate conductivity model shown in Figure 2. Two transmitting frequencies 0.5 and $1.25 \mathrm{~Hz}$ are used.

a)

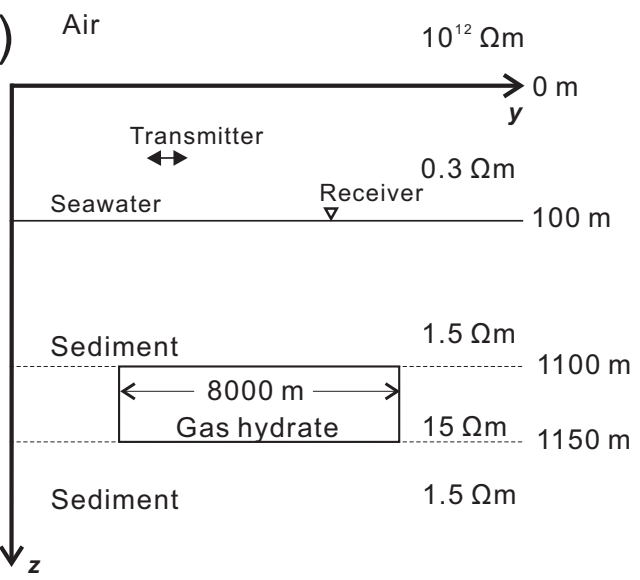

b)

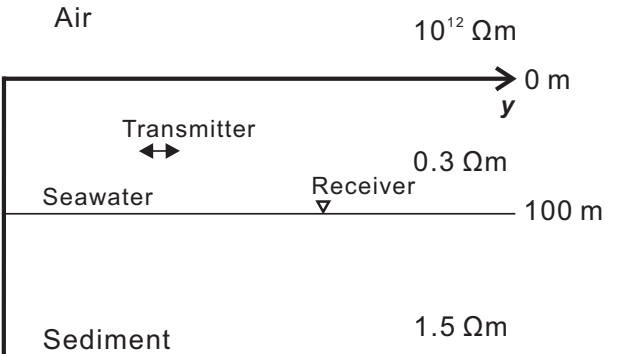

Sediment

Figure 4. The 2D gas hydrate conductivity model (a) and its background model (b) without the hydrate layer.

Figure 5 shows the results for the original electric field, the weighted differential field (Figure 5a) and their corresponding detectivity (Figure 5b). The 2D numerical results also indicate that the original field is masked by the airwave and it cannot be used for identifying the gas hydrate target, while the weighted differential field is less affected by the airwave and it shows evident correspondence to the hydrate. Our results indicate that 
the pre-processing of the EM field data is necessary before interpretation. For our tests, the weighted differences of the original fields are proved to be effective in removing the airwave in shallow waters with gas hydrate targets.
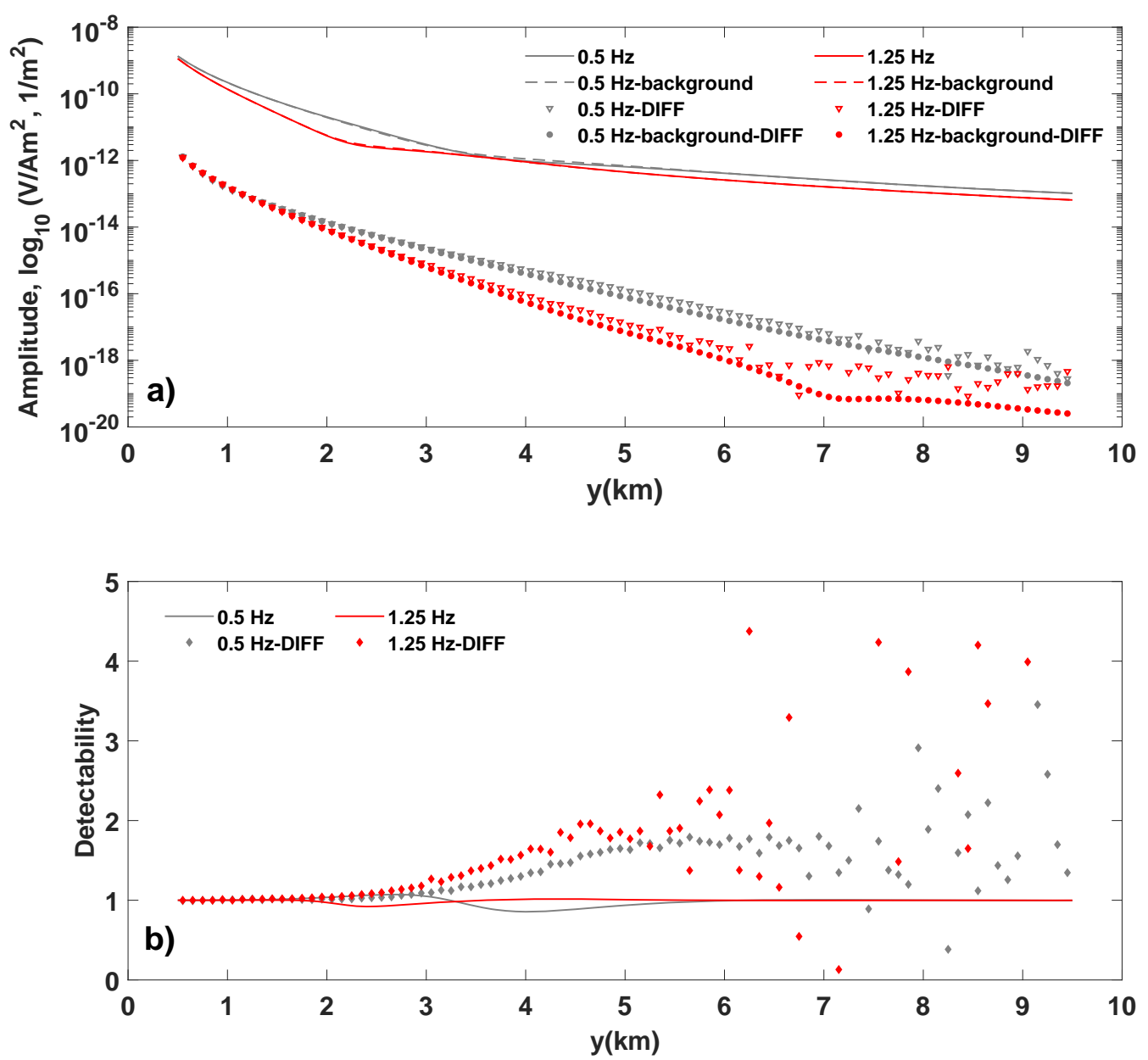

Figure 5. The amplitude of inline electric field and its weighted differences (a), and the corresponding detectivity (b) for the 2D gas hydrate conductivity model shown in Figure 4. Two transmitting frequencies 0.5 and $1.25 \mathrm{~Hz}$ are used.

\section{Conclusions}

In this study, we apply the weighted differential approach to process the marine CSEM data in shallow water areas with gas hydrate targets. The weighted differential field accounts for the geometric spreading factor of the EM fields and it is effective in suppressing the airwave.

The original shallow water data cannot be used directly for investigating the hydrate as it is masked by the airwave. We conduct both 1D and 2D numerical analysis and our tests show that the detectivity of the gas hydrate deposits is significantly improved, which indicates that the airwave is effectively suppressed in the weighted differential field data. The weighted differential data shows an evident correlation with the seafloor buried hydrates and it is proved to be effective in attenuating the airwave in shallow waters.

For the future work, the 3D numerical analysis will be performed. The weighted differential field can also be extended to deal with the anisotropic data. The field data will also be tested for validating the weighted differential approach used. 
Author Contributions: This study is the result of collaborative teamwork. Conceptualization,
methodology, software and investigation, G.L. and Y.L.; visualization, F.T., C.L. and W.L.; funding ac-
quisition, G.L. and Y.L. All authors have read and agreed to the published version of the manuscript.

Funding: This work was funded by the National Natural Science Foundation of China under Grant Nos 42076060 and 41904074, the Open Fund of the Key Laboratory of Ocean and Marginal Sea Geology, Chinese Academy of Sciences under Grant No. OMG2020-01, and the Open Fund of the Key Laboratory of Marine Geology and Environment, Chinese Academy of Sciences under grant No. MGE2020KG0.

\section{Institutional Review Board Statement: Not applicable.}

Informed Consent Statement: Not applicable

Data Availability Statement: Data associated with this research are available and can be obtained by contacting the corresponding author.

Acknowledgments: We appreciate the comments from two anonymous reviewers which greatly improved the manuscript.

Conflicts of Interest: The authors declare no conflict of interest.

\section{References}

1. Minshull, T.A.; Marín-Moreno, H.; Betlem, P.; Bialas, J.; Buenz, S.; Burwicz, E.; Cameselle, A.L.; Cifci, G.; Giustiniani, M.; Hillman, J.I.; et al. Hydrate occurrence in Europe: A review of available evidence. Mar. Pet. Geol. 2019, 111, 735-764. [CrossRef]

2. Hassanpouryouzband, A.; Joonaki, E.; Farahani, M.V.; Takeya, S.; Ruppel, C.; Yang, J.; English, N.J.; Schicks, J.M.; Edlmann, K.; Mehrabian, H.; et al. Gas hydrates in sustainable chemistry. Chem. Soc. Rev. 2020, 49, 5225-5309. [CrossRef] [PubMed]

3. Zander, T. Methane Hydrates in Black Sea Deep-Sea Fans: Characteristics, Implications, and Related Geohazards. Ph.D. Thesis, University of Kiel: Kiel, Germany, 2017.

4. Goswami, B.K. A Joint Electromagnetic and Seismic Study of Arctic Hydrates and Fluid Escape Features, Offshore SVALBARD. Ph.D. Thesis, University of Southampton: Southampton, UK, 2016.

5. Kopp, H.; Chiocci, F.L.; Berndt, C.; O̧ağatay, N.; Ferreira, T.; Fortes, J.; Gràcia, E.; Vega, A.G.; Kopf, A.; Sørensen, M.; et al. Marine Geohazards: Safeguarding Society and the Blue Economy from a Hidden Threat; Position Paper 26 of the European Marine Board; European Marine Board IVZW: Ostend, Belgium, 2021. [CrossRef]

6. Hassanpouryouzband, A.; Yang, J.; Tohidi, B.; Chuvilin, E.; Istomin, V.; Bukhanov, B. Geological $\mathrm{CO}_{2} \mathrm{Capture}$ and Storage with Flue Gas Hydrate Formation in Frozen and Unfrozen Sediments: Method Development, Real Time-Scale Kinetic Characteristics, Efficiency, and Clathrate Structural Transition. ACS Sustain. Chem. Eng. 2019, 7, 5338-5345. [CrossRef]

7. Judd, A.; Hovland, M. Seabed Fluid Flow: The Impact on Geology, Biology and the Marine Environment; Cambridge University Press: Cambridge, UK, 2007.

8. Riedel, M.; Willoughby, E.C.; Chopra, S. (Eds.) Geophysical Characterization of Gas Hydrates; Society of Exploration Geophysicists (SEG): Tulsa, UK, USA, 2010. [CrossRef]

9. Rajput, S.; Thakur, N.K. Exploration of Gas Hydrates; Springer: Berlin/Heidelberg, Germany, 2011. [CrossRef]

10. Hovland, M.; Judd, A. Seabed Pockmarks and Seepages: Impact on Geology, Biology and the Marine Environment; Graham \& Trotman: London, UK, 1988. [CrossRef]

11. Ceramicola, S.; DupréLuis, S.; Woodside, S. Cold Seep Systems; Sringer: Berlin/Heidelberg, Germany, 1988; pp. 367-387._19. [CrossRef]

12. Jaśniewicz, D.; Klusek, Z.; Brodecka-Goluch, A.; Bolałek, J. Acoustic investigations of shallow gas in the southern Baltic Sea (Polish Exclusive Economic Zone): A review. Geo-Mar. Lett. 2019, 39, 1-17. [CrossRef]

13. Andreassen, K.; Hart, P.E.; MacKay, M. Amplitude versus offset modeling of the bottom simulating reflection associated with submarine gas hydrates. Mar. Geol. 1997, 137, 25-40. [CrossRef]

14. Korenga, J.; Holbrook, W.S.; Singh, S.C.; Minshull, T.A. Natural gas hydrates on the southeast U.S. margin: Constraints from full waveform and travel time inversions of wide-angle seismic data. J. Geophys. Res. 1997, 102, 15345-15365. [CrossRef]

15. Shankar, U.; Sinha, B.; Thakur, N.K.; Khanna, R. Amplitude-versus-offset modeling of the bottom simulating reflection associated with submarine gas hydrates. Mar. Geophys. Res. 2005, 26, 29-35. [CrossRef]

16. Jaiswal, P.; Dewangan, P.; Ramprasad, T.; Zelt, C.A. Seismic characterization of hydrates in faulted, fine-grained sediments of Krishna-Godavari Basin: Full waveform inversion. J. Geophys. Res. 2012, 117, B10305. [CrossRef]

17. Rajput, S.; Müller, T.M.; Clennell, M.B.; Rao, P.P.; Thakur, N. Constraints on seismic reflections and mode conversions at bottom simulating reflectors associated with gas hydrates. J. Pet. Sci. Eng. 2012, 88-89, 48-60. [CrossRef]

18. Berndt, C.; Chi, W.; Jegen, M.; Lebas, E.; Crutchley, G.; Muff, S.; Hölz, S.; Sommer, M.; Lin, S.; Liu, C.; et al. Tectonic controls on gas hydrate distribution of SW Taiwan. J. Geophys. Res. Solid Earth 2019, 124, 1164-1184. [CrossRef]

19. Zander, T.; Haeckel, M.; Berndt, C.; Chi, W.C.; Klaucke, I.; Bialas, J.; Klaeschen, D.; Koch, S.; Atginc, O. On the origin of multiple BSRs in the Danube deep-sea fan, Black Sea. Earth Planet. Sci. Lett. 2017, 462, 15-25. [CrossRef] 
20. Edwards, R.N. On the resource evaluation of marine gas hydrate deposits using sea-floor transient electric dipole-dipole methods. Geophysics 1997, 62, 63-74. [CrossRef]

21. Weitemeyer, K.; Constable, S.; Key, K. Marine EM techniques for gas-hydrate detection and hazard mitigation. Lead. Edge 2006, 25, 629-632. [CrossRef]

22. Weitemeyer, K.A.; Constable, S.C.; Key, K.W.; Behrens, J.P. First results from a marine controlled-source electromagnetic survey to detect gas hydrates offshore Oregon. Geophys. Res. Lett. 2006, 33, L03304. [CrossRef]

23. Weitemeyer, K.; Constable, S. Mapping shallow geology and gas hydrate with marine CSEM surveys. First Break 2010, $28,97-102$. [CrossRef]

24. Lee, K.H.; Jang, H.; Jang, H.; Kim, H.J. Sensitivity analysis of marine controlled-source electromagnetic methods to a shallow gas-hydrate layer with 1D forward modeling. Geosci. J. 2011, 15, 297-303. [CrossRef]

25. Weitemeyer, K.A.; Constable, S.; Tréhu, A.M. A marine electromagnetic survey to detect gas hydrate at Hydrate Ridge, Oregon. Geophys. J. Int. 2011, 187, 45-62. [CrossRef]

26. Swidinsky, A.; Edwards, R.N.; Jegen, M. The marine controlled source electromagnetic response of a steel borehole casing: Applications for the NEPTUNE Canada gas hydrate observatory. Geophys. Prospect. 2013, 61, 842-856. [CrossRef]

27. Hsu, S.K.; Chiang, C.W.; Evans, R.L.; Chen, C.S.; Chiu, S.D.; Ma, Y.F.; Chen, S.C.; Tsai, C.H.; Lin, S.S.; Wang, Y. Marine controlled source electromagnetic method used for the gas hydrate investigation in the offshore area of SW Taiwan. J. Asian Earth Sci. 2014, 92, 224-232. [CrossRef]

28. Goswami, B.K.; Weitemeyer, K.A.; Minshull, T.A.; Sinha, M.C.; Westbrook, G.K.; Chabert, A.; Henstock, T.J.; Ker, S. A joint electromagnetic and seismic study of an active pockmark within the hydrate stability field at the Vestnesa Ridge, West Svalbard margin. J. Geophys. Res. Solid Earth 2015, 120, 6797-6822. [CrossRef]

29. Attias, E.; Weitemeyer, K.; Minshull, T.A.; Best, A.I.; Sinha, M.; Jegen-Kulcsar, M.; Hölz, S.; Berndt, C. Controlled-source electromagnetic and seismic delineation of subseafloor fluid flow structures in a gas hydrate province, offshore Norway. Geophys. J. Int. 2016, 206, 1093-1110. [CrossRef]

30. Li, G.; Han, B. Application of the perfectly matched layer in 2.5D marine controlled-source electromagnetic modeling. Phys. Earth Planet. Inter. 2017, 270, 157-167. [CrossRef]

31. Schwalenberg, K.; Rippe, D.; Koch, S.; Scholl, C. Marine-controlled source electromagnetic study of methane seeps and gas hydrates at Opouawe Bank, Hikurangi Margin, New Zealand. J. Geophys. Res. Solid Earth 2017, 122, 3334-3350. [CrossRef]

32. Li, G.; Li, Y.; Han, B. Accurate Interpolation at receiver positions: A novel method for frequency-domain marine CSEM finite-difference modelling. Pure Appl. Geophys. 2017, 174, 2143-2160. [CrossRef]

33. Attias, E.; Weitemeyer, K.; Hölz, S.; Naif, S.; Minshull, T.A.; Best, A.I.; Haroon, A.; Jegen-Kulcsar, M.; Berndt, C. High-resolution resistivity imaging of marine gas hydrate structures by combined inversion of CSEM towed and ocean-bottom receiver data. Geophys. J. Int. 2018, 214, 1701-1714. [CrossRef]

34. Li, G.; Li, Y.; Han, B.; Liu, Z. Application of the perfectly matched layer in 3-D marine controlled-source electromagnetic modelling. Geophys. J. Int. 2018, 212, 333-344. [CrossRef]

35. Li, G.; Cai, H.; Li, C.F. Alternating joint inversion of controlled-source electromagnetic and seismic data using the joint total variation constraint. IEEE Trans. Geosci. Remote Sens. 2019, 57, 5914-5922. [CrossRef]

36. Attias, E.; Amalokwu, K.; Watts, M.; Falcon-Suarez, I.H.; North, L.; Hu, G.W.; Best, A.I.; Weitemeyer, K.; Minshull, T.A. Gas hydrate quantification at a pockmark offshore Norway from joint effective medium modelling of resistivity and seismic velocity. Mar. Pet. Geol. 2020, 113, 104151. [CrossRef]

37. Li, G.; Duan, S.; Cai, H.; Han, B.; Ye, Y. An improved interpolation scheme at receiver positions for 2.5D frequency-domain marine controlled-source EM forward modeling. Geophys. Prospect. 2020, 68, 1657-1675. [CrossRef]

38. Kannberg, P.K.; Constable, S. Characterization and quantification of gas hydrates in the California Borderlands. Geophys. Res. Lett. 2020, 47, e2019GL084703. [CrossRef]

39. Schwalenberg, K.; Willoughby, E.; Mir, R.; Edwards, R.N. Marine gas hydrate electromagnetic signatures in Cascadia and their correlation with seismic blank zones. First Break 2005, 23, 57-63. [CrossRef]

40. Goswami, B.K.; Weitemeyer, K.A.; Minshull, T.A.; Sinha, M.C.; Westbrook, G.K.; Marín-Moreno, H. Resistivity image beneath an area of active methane seeps in the west Svalbard continental slope. Geophys. J. Int. 2016, 207, 1286-1302. [CrossRef]

41. Schwalenberg, K.; Gehrmann, R.A.; Bialas, J.; Rippe, D. Analysis of marine controlled source electromagnetic data for the assessment of gashydrates in the Danube deep-sea fan, Black Sea. Mar. Pet. Geol. 2020, 122, 104650 doi: 10.1016/j.marpetgeo.2020.104650. [CrossRef]

42. Duan, S.; Hölz, S.; Dannowski, A.; Schwalenberg, K.; Jegen, M. Study on gas hydrate targets in the Danube Paleo-Delta with a dual polarization controlled-source electromagnetic system. Mar. Pet. Geol. 2021, 134, 105330. [CrossRef]

43. Sun, Y.F.; Goldberg, D. Dielectric method of high-resolution gas hydrate estimation. Geophys. Res. Lett. 2005, 32. [CrossRef]

44. Sun, Y.; Goldberg, D.; Collett, T.; Hunter, R. High-resolution well-log derived dielectric properties of gas-hydrate-bearing sediments, Mount Elbert Gas Hydrate Stratigraphic Test Well, Alaska North Slope. Mar. Pet. Geol. 2011, 28, 450-459. [CrossRef]

45. Hyndman, R.D.; Yuan, T.; Moran, K. The concentration of deep sea gas hydrates from downhole electrical resistivity logs and laboratory data. Earth Planet. Sci. Lett. 1999, 172, 167-177. [CrossRef]

46. Cook, A.E.; Anderson, B.I.; Malinverno, A.; Mrozewski, S.; Goldberg, D.S. Electrical anisotropy due to gas hydrate-filled fractures. Geophysics 2010, 75, F173-F185. [CrossRef] 
47. Kim, G.Y.; Yi, B.Y.; Yoo, D.G.; Ryu, B.J.; Riedel, M. Evidence of gas hydrate from downhole logging data in the Ulleung Basin, East Sea. Mar. Pet. Geol. 2011, 28, 1979-1985. [CrossRef]

48. Lee, M.W.; Collett, T.S. In-situ gas hydrate hydrate saturation estimated from various well logs at the Mount Elbert Gas Hydrate Stratigraphic Test Well, Alaska North Slope. Mar. Pet. Geol. 2011, 28, 439-449. [CrossRef]

49. Goswami, B.K.; Weitemeyer, K.A.; Timothy A.; Minshull, S.B.; Westbrook, G.K.; Ker, S.; Sinha, M.C. Variations in pockmark composition at the Vestnesa Ridge: Insights from marine controlled source electromagnetic and seismic data. Geochem. Geophys. Geosystems 2017, 18, 1111-1125. [CrossRef]

50. Bernard, B.B.; Brooks, J.M.; Sackett, W.M. Natural gas seepage in the Gulf of Mexico. Earth Planet. Sci. Lett. 1976, 31, 48-54. [CrossRef]

51. Martinelli, G.; Panahi, B. (Eds.). Mud Volcanoes, Geodynamics and Seismicity; Springer: Berlin/Heidelberg, Germany, 2005. [CrossRef]

52. Bünz, S.; Polyanov, S.; Vadakkepuliyambatta, S.; Consolaro, C.; Mienert, J. Active gas venting through hydrate-bearing sediments on the Vestnesa Ridge, offshore W-Svalbard. Mar. Geol. 2012, 332-334, 189-197. [CrossRef]

53. Talukder, A.R. Review of submarine cold seep plumbing systems: Leakage to seepage and venting. Terra Nova 2012, 24, 255-272. [CrossRef]

54. Micallef, A.; Krastel, S.; Savini, A. (Eds.) Submarine Geomorphology; Springer: Berlin/Heidelberg, Germany, 2018. [CrossRef]

55. Hachikubo, A.; Minami, H.; Yamashita, S.; Khabuev, A.; Krylov, A.; Kalmychkov, G.; Poort, J.; Batist, M.D.; Henskiy, A.C.; Manakov, A.; et al. Characteristics of hydrate-bound gas retrieved at the Kedr mud volcano (southern Lake Baikal). Sci. Rep. 2020, 10, 14747. [CrossRef] [PubMed]

56. Baba, K. Electrical structure in marine tectonic settings. Surv. Geophys. 2005, 26, 701-731. [CrossRef]

57. Zhdanov, M.S. Electromagnetic geophysics: Notes from the past and the road ahead. Geophysics 2010, 75, 75A49-75A66. [CrossRef]

58. Key, K. Marine electromagnetic studies of seafloor resources and tectonics. Surv. Geophys. 2011, 33, 135-167. doi: 10.1007/s10712-011-9139-x. [CrossRef]

59. Constable, S. Review paper: Instrumentation for marine magnetotelluric and controlled source electromagnetic sounding. Geophys. Prospect. 2013, 61, 505-532. [CrossRef]

60. Key, K. Application of broadband marine magnetotelluric exploration to a 3D salt structure and a fast-spreading ridge. Ph.D. Thesis, University of California, San Diego, CA, USA, 2003.

61. Hölz, S.; Swidinsky, A.; Sommer, M.; Jegen, M.; Bialas, J. The use of rotational invariants for the interpretation of marine CSEM data with a case study from the North Alex mud volcano, West Nile Delta. Geophys. J. Int. 2015, 201, 224-245. [CrossRef]

62. Nordskag, J.I.; Amundsen, L. Asymptotic airwave modeling for marine controlled-source electromagnetic surveying. Geophysics 2007, 72, F249-F255. [CrossRef]

63. Løseth, L.O.; Amundsen, L.; Jenssen, A.J. A solution to the airwave-removal problem in shallow-water marine EM. Geophysics 2010, 75, A37-A42. [CrossRef]

64. Chen, J.; Alumbaugh, D.L. Three methods for mitigating airwaves in shallow water marine controlled-source electromagnetic data. Geophysics 2011, 76, F89-F99. [CrossRef]

65. Hunziker, J.; Slob, E.; Mulder, W. Effects of the airwave in time-domain marine controlled-source electromagnetics. Geophysics 2011, 76, F251-F261. [CrossRef]

66. Mittet, R.; Morten, J.P. The marine controlled-source electromagnetic method in shallow water. Geophysics 2013, 78, E67-E77. [CrossRef]

67. Amundsen, L.; Løseth, L.; Mittet, R.; Ellingsrud, S.; Ursin, B. Decomposition of electromagnetic fields into upgoing and downgoing components. Geophysics 2006, 71, G211-G223. [CrossRef]

68. Mittet, R. Normalized amplitude ratios for frequency-domain CSEM in very shallow water. First Break 2008, 26, 47-54. [CrossRef]

69. Li, G.; Zhang, L.; Goswami, B.K. Complex frequency-shifted perfectly matched layers for 2.5D frequency-domain marine controlled source EM field simulations. Surv. Geophys. 2021, submitted.

70. Wait, J.R. The electromagnetic fields of a horizontal dipole in the presence of a conducting half-space. Can. J. Phys. 1961, 39, 1017-1027. [CrossRef]

71. Ward, S.H.; Hohmann, G.W. Electromagnetic Theory for Geophysical Applications; Society of Exploration Geophysicists (SEG): Tulsa, OK, USA, 1988; pp. 130-311. [CrossRef]

72. Løseth, L.O.; Ursin, B. Electromagnetic fields in planarly layered anisotropic media. Geophys. J. Int. 2007, 170, 44-80. [CrossRef]

73. Li, Y.; Li, G. Electromagnetic field expressions in the wavenumber domain from both the horizontal and vertical electric dipoles. J. Geophys. Eng. 2016, 13, 505-515. [CrossRef]

74. Li, G.; Li, Y. Joint inversion for transmitter navigation and seafloor resistivity for frequency-domain marine CSEM data. J. Appl. Geophys. 2017, 136, 178-189. [CrossRef]

75. Løseth, L.O.; Amundsen, L. Removal of air-response by weighting inline and broadside CSEM/SBL data. In SEG Technical Program Expanded Abstracts 2007; Society of Exploration Geophysicists (SEG): Tulsa, OK, USA, 2007; pp. 1460-1464. [CrossRef]

76. Constable, S.; Weiss, C.J. Mapping thin resistors and hydrocarbons with marine EM methods: Insights from 1D modeling. Geophysics 2006, 71, G43-G51. [CrossRef] 